Technological University Dublin

DƯBLIN

ARROW@TU Dublin

Articles

Dublin School of Architecture

2002-07-01

\title{
All American: Innovation in American Architecture
}

Noel Brady

Technological University Dublin, noel.brady@tudublin.ie

Follow this and additional works at: https://arrow.tudublin.ie/bescharcart

Part of the Architecture Commons

\section{Recommended Citation}

Brady, N.: All American: Innovation in American Architecture. Irish architect, 2002 July-Aug., n.179, p.59. doi:10.21427/D7D511

This Review is brought to you for free and open access by the Dublin School of Architecture at ARROW@TU Dublin. It has been accepted for inclusion in Articles by an authorized administrator of ARROW@TU Dublin. For more information, please contact arrow.admin@tudublin.ie, aisling.coyne@tudublin.ie,gerard.connolly@tudublin.ie.

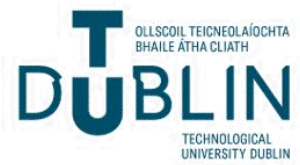




\title{
School of Architecture \\ Articles
}

Dublin Institute of Technology

Year 2002

\section{All American: innovation in American architecture}

\author{
Noel J. Brady \\ Dublin Institute of Technology, noel.brady@dit.ie
}

This paper is posted at ARROW@DIT.

http://arrow.dit.ie/bescharcart/1 


\section{— Use Licence}

\section{Attribution-NonCommercial-ShareAlike 1.0}

You are free:

- to copy, distribute, display, and perform the work

- to make derivative works

Under the following conditions:

- Attribution.

You must give the original author credit.

- Non-Commercial.

You may not use this work for commercial purposes.

- Share Alike.

If you alter, transform, or build upon this work, you may distribute the resulting work only under a license identical to this one.

For any reuse or distribution, you must make clear to others the license terms of this work. Any of these conditions can be waived if you get permission from the author.

Your fair use and other rights are in no way affected by the above.

This work is licensed under the Creative Commons Attribution-NonCommercialShareAlike License. To view a copy of this license, visit:

- URL (human-readable summary):

http://creativecommons.org/licenses/by-nc-sa/1.0/

- URL (legal code):

http://creativecommons.org/worldwide/uk/translated-license 


\section{All American}

\section{Innovation in American Architecture}

by Brian Carter \& Annette Lecuyer

Review by Noel J. Brady

As a review of current architectural thinking in American Architecture, this book features 23 younger practices, mostly in their 40's representing approximately 10 US states. Framed between two essays, the work is explained through photographs, some models and drawings. The latter are reproduced as white lines on blue backgrounds, which can sometimes be difficult to read. In the first essay, "The Critical Edge", the record reports that even though there is one architect for every 2600 of population (perhaps even a better proportion than Ireland) the market forces that drive the cultural and economic scene have given rise to buildings that are "pragmatic, short lived and disposable" and makes the observation that "the overriding architectural culture in America has become more conservative". In spite of a few architects succeeding internationally and significant economic expansion, architectural patronage is lacking.

This essay decries the lack of a social democratic model to boost socially responsive and publicly oriented architectural investment but acknowledges the increased role of federal funding and support from the Graham Foundation for Advanced Studies in the Arts and the National Endowment for the Arts. With only two home-based architectural publications it is a significant uphill struggle. What does emerge in this essay is that, within the confines of this conservative,

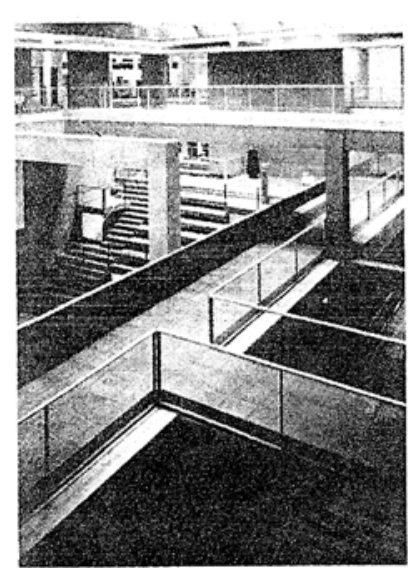

pragmatic and industrialised culture, architects are finding a way to subvert standardisation in search of a contemporary expression: a hand made industrialised product. The essay concludes that "where their preoccupations (architects) are wideranging, the quality of their work represents a narrow bandwidth, (....) moving beyond the limits of the commodified norm to produce architecture that is thoughtfully conceived and executed" a "product of creative friction between the ideal and the real".

Constructive Dialogues

By subverting the nature of industrial practice, architects such as the Architectural Research Office and Guthrie Buresh seek to use everyday materials in new ways. Wendell Burnett and Daly Glenik successfully transcend the discipline of modularisation and, even if Thomas Phifer seeks a more normative approach, the work shows that industry might be tamed in the tradition of Schindler and Eames with more than a nod towards Norman Foster. The demands of rapid production schedules and tight budgets are forcing Kennedy and Violich Architects and ShoP to seek out new methodologies, relying on either in-house workshops or digitally exported templates where specialist fabricators assemble them on site. This may become a model for architectural production in future.

\section{Reflective Art}

Represented by Diller and Scofido Architects and Allied Works. It is the former who dominate the landscape. With several years of mainly art practice behind them, Diller and Scafido are now finding a role in mainstream practice. One cannot help feeling that something is lost in the translation.

\section{Digital Dreams}

It would be expected that the

most industrialised society on Earth
should lead digital innovation and creation, yet this setion appears lack lustre by European standards and the execution of the completed works are seriously compromised by the realities of construction. If the digital dream of new environments that computers promise is to succeed, it must be capable of living in the "real world". The work, especially that of Greg Lynn (Form) and Michael McInturf and Office $\mathrm{dA}$, indicates the extensive superstructure that allows the free form to exist.

\section{Plywood and other meditations}

Plywood dominates every work, making sense of the post industrialised, post modern landscape; standard, consistent and yet malleable, capable of being both structure and shelter. A product of World War expediencies, it became the ideal module for track housing, shopping malls and office developments. Here plywood and other mass produced materials are cut, moulded, deformed, cut, routed and milled. But where the work is most hopeful, is where the idea of place, landscape and people emerges to give witness to the unbounded optimism that can exist in America. In the work of Rick Joy, the Building Workshop, Charles Rose and Vincent James Associates the advantages of industrialisation, CAD/CAM and self-built are sublimated into a more inclusive environment.

The book is a useful guide to the constructive possibilities within current American Architecture, forgiving that $80 \%$ is missing, of what is possible when architecture is freed of overtly restrictive or conservative norms or regulation and receives innovative patronage.

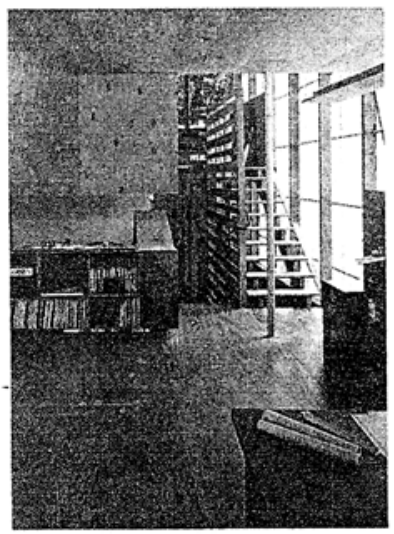

All American Innovation in American Architecture By Brian Carter and Annette LeCuyer Published by Thames \& Hudson ISBN 0500341826,256 pp, 389 iflustrations Price f24.95 Sterling (hardback)

Noel Brady received a Diploma in Architecture from DIT (Bolton Street) before completing graduate studies at MIT (USA). He established NJBA Architects \& Urban Designers in 1994 and has been the 4th year studio master at the School of Architecture DIT since 2000. 